University for Business and Technology in Kosovo

UBT Knowledge Center

Oct 28th, 9:00 AM - Oct 30th, 5:00 PM

\title{
Physical-Chemical characteristics of the Substances Before and After the discharge of factories of the detergents that can cause increase of the degree of the eutrophication of surface waters in the city of Prizren
}

\author{
Sami Gashi \\ University for Business and Technology, sami.gashi@outlook.com \\ Ymerr Bajmaku \\ University for Business and Technology, ymerbajmaku@hotmail.com \\ Petrit Drini \\ University for Business and Technology, petritdrini@yahoo.com
}

Follow this and additional works at: https://knowledgecenter.ubt-uni.net/conference

Part of the Engineering Commons, and the Physical Sciences and Mathematics Commons

\section{Recommended Citation}

Gashi, Sami; Bajmaku, Ymerr; and Drini, Petrit, "Physical-Chemical characteristics of the Substances Before and After the discharge of factories of the detergents that can cause increase of the degree of the eutrophication of surface waters in the city of Prizren" (2016). UBT International Conference. 43. https://knowledgecenter.ubt-uni.net/conference/2016/all-events/43

This Event is brought to you for free and open access by the Publication and Journals at UBT Knowledge Center. It has been accepted for inclusion in UBT International Conference by an authorized administrator of UBT Knowledge Center. For more information, please contact knowledge.center@ubt-uni.net. 
Book of Proceedings

International Conference on Mechatronics, Sciences in Energy Efficiency Engineering,

System Engineering and Robotics

\title{
Physical-Chemical characteristics of the Substances Before and After the discharge of factories of the detergents that can cause increase of the degree of the eutrophication of surface waters in the city of Prizren
}

\author{
Sami Gashi ${ }^{1}$, Ymerr Bajmaku ${ }^{2}$, Petrit Drini $^{3}$ \\ ${ }^{1,2,3}$ UBT - Higher Education Institution, Lagjja Kalabria, 10000 p.n., \\ Prishtine, Kosovo \\ Gymnasium “Gjon Buzuku”, Prizren, \\ Factory of Zinc Galvanism, Prizren, \\ sami.gashi@outlook.com ymerbajmaku@hotmail.com \\ petritdrini@yahoo.com
}

\begin{abstract}
Industrial discharge waters, especially those of producers of detergents are one of the main polluters of surface waters in Prizren. The greatest polluters are: vehicle laundry and laundry of mega clothes, as well as factories producing liquid detergents, as well as powder ones. Concentration of active substances and perborate polyphosphate detergents also increase the wastewater from households. Therefore, we can say that the washing detergents, cleaning, are not safe for the environment, all of those are in varying degrees dangerous pollutants. Their presence represents the most acute problem of water supply in the city of Prizren. In this paper are treated physico-chemical indicators of pollution that may be caused by emissions from factories producing washing substances in the region of Prizren, Kosovo. And especially, will be treated contaminants from the manufacturing industry to washing agents, whose production due to massive use causes the polluting of current waters. This has happened because they have not paid attention to the chemical and physical- chemical features of phosphates and other compounds that affect eutrophication of Lumbardhi River. The problem of eutrophication also represents a form of disruption of the ecological balance of nature and consist with increasing phosphorus compounds in waters, where it causes the rapid development of the planktons and algae, causing damage to water quality. The Microbiologic problem of dissolution of tensids even at low concentrations causes creating dense and stable foam in waters surface, which prevents digestion of oxygen from the air into the water and thus the question of the survival of flora and fauna in those waters of the river Lumbardhi, as well as its use for drinks. This problem is caused by the wide use of detergents that contained tensids with branched range of hydrocarbons, which as the main representative is dodecyl benzene - sulfonate of tetramer type.
\end{abstract}

Keywords: detergents, tensioactive substances (LAB-sulfonate), total phosphorus, sodium tripolyphosphate, sodium perborate. 
Physical-Chemical characteristics of the Substances Before and After the discharge of factories of the detergents that can cause increase of the degree of the eutrophication of surface waters in the city of Prizren

\section{Introduction}

The river Lumbardhi runs along the midst of Prizren city. The main sources of this river are those of Mount Lumbardhi, height $2640 \mathrm{~m}$ [8]. The urban area of Prizren has potential for water pollution in many ways. This way, from the street, the carriers of pollution are vehicles, such as tires, oil, heavy metals, various oils and other ways of contamination. Untreated sewage or poorly treated can influence the reduction of dissolved oxygen value and this leads to increased fecal contaminants like bacteria, nitrates, phosphorus and other chemicals. In this paper will be treated and evaluated experimentally the river pollution rate of Lumbardhi from the discharged pollutants from the urban area, especially from the manufacturing factory of detergents "ABI". The slogan "Chemistry in our everyday life - washing agents" includes basic and general knowledge of the washing agents for the public as a whole and emancipation of consumers about the effects of ecological possibilities of alleviating the negative impact of washing agents in our environment where we live[3].

Waters, under natural conditions (unpolluted), have relatively low content of phosphorus; in these cases, the water view is sober, less or no vegetation and the end of the river is clean. This water is named "oligotrophic". But, eutrophic waters are green in color, dim and viscous as well as their translucency is low.

Therefore, there are attempts to find an adequate replacement of phosphates in various detergents formations. A biological control of roads is reducing the amount of phosphorus in water through special pools in which are cultivated algae, which can be used as animal feed. However, eutrophication is a complex process, which can not only be linked to a harmful substance (e.g. phosphorus) but from a range of harmful substances (manganese, iron, ammonia, silica, etc.). Therefore, the elimination of only one substance is not the solution of this problem, especially if it is only for a pollutant, as is e.g. industry of washing agents.

And every European country has their own internal regulations on the maximum amount of phosphates that should contain detergents and in some countries it is illegal to use detergents with polyphosphate but only with zeolite

In Kosovo, there are no treatment plants of urban waste water and industrial waters. Industrial waters are one of the main polluters of surface and groundwater. Treatment of discharged urban wastewater and industrial ones in Prizren areas in fact are non-existent, with the exception of some septic tanks for household restricted areas or natural lagoons which are formed in the points collection systems discharging wastewater.

Wastewater discharges constitute the main source of pollution of natural waters because they contain many substances that consume dissolved oxygen: soluble phosphorus compounds (eutrophication), and detergents that affect water quality. In terms of management of wastewater, Kosovo will face major challenges, particularly in relation to the implementation of EU directives (Directive 91/271 / EEC on treatment of urban wastewater) and the fulfillment of international obligations. This given the fact that Kosovo's rivers pass through neighboring countries. However, Kosovo still does not have a strategy for managing wastewater and creating functional mechanisms for the financing of waste water treatment. 


\section{Book of Proceedings}

International Conference on Mechatronics, Sciences in Energy Efficiency Engineering,

System Engineering and Robotics

\section{Material and methods}

Sampling of water for laboratory analysis is done carefully. In this paper we are dealing with water sampling: those virgin ones, water discharge channels for the manufacturer of detergents and water sampling of rivers, always respecting the following rules and based on standards. So, according to this technique should be excluded a possibility of contamination from the outside; from the person who takes the sample or any other factor[4].

During sampling an important role had meteorological factors that should be recorded depending on the time interval.

Meteorological factors are:a. Time (sunny, rainy, snowy, etc.); b. Temperature;

c. Time and $d$. The water temperature of the sampling point ${ }^{[6]}$.

Sampling for analysis in the scientific work is done in the time interval from September to October 2016.

The purpose of obtaining the sample is collection and sending water samples for laboratory examination. Sampling method is important as well as laboratory analysis. Therefore, and utmost care should be made in order not to contaminate the obtained samples during transportation to the respective laboratory for physical-chemical and bacteriological analysis. Bacteriological analysis is intended to show whether water contains micro-organisms harmful to health and are indicators for further processing and disinfection of drinking water. Chemical analysis shows the amount of needed chemical ingredients and harmful ones in drinking water ${ }^{[7]}$.

\subsection{Sample}

Samples for laboratory analysis for determination of the physical - chemical "AB" are done at four locations (site-sampling) fountain-head (the water supply of the city, virgin samples) marked with AB1, drain pipe (water after the production process) marked with $\mathrm{AB} 2$, the drain pipe into the city sewage marked with AB3 and into the sewage before discharge into Lumbardhi of Prizren marked with AB4. Samples are taken in time intervals:

- AB1 - fountain-head: on 06/10/2016 at $12 \mathrm{~h} 20$ min. sunny weather.

- AB2 - drain pipe: on 10/06/2016 at $12 \mathrm{~h} 30$ min. sunny weather.

- AB3 - drain pipe into the city sewage: on 10.06 .2016 at $14 \mathrm{~h}$ and $05 \mathrm{~min}$. Sunny weather.

- AB4 - Sewage before discharge into Lumbardhi of Prizren: on 10/06/2016 at 14h 35 min. Sunny weather.

Analysis of the samples were made in the laboratory of the Hydro Meteorological Institute - Pristina. In the following figure is shown the map of the sampling points of the "AB". 
Physical-Chemical characteristics of the Substances Before and After the discharge of factories of the detergents that can cause increase of the degree of the eutrophication of surface waters in the city of Prizren

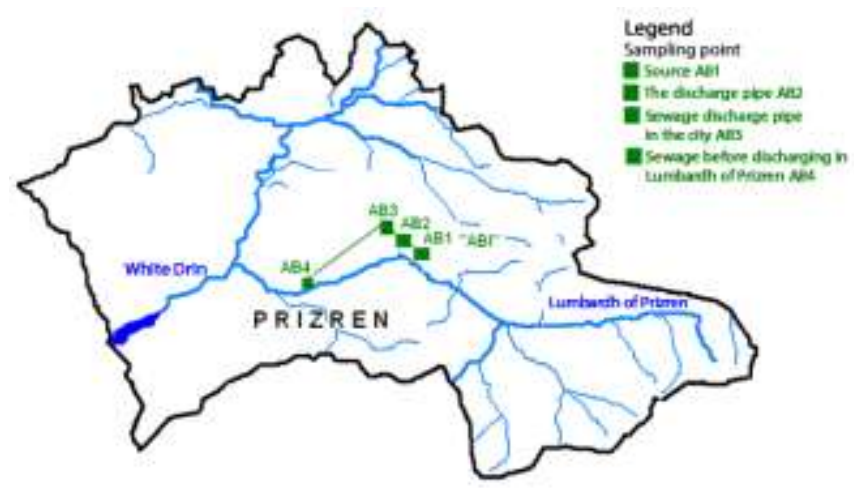

Fig. 1. Presentation of four site-sampling of "AB" on the map of the territory of the Municipality of Prizren

\subsection{Results and discussions}

The results obtained from the manufacturer of liquid detergents "AB" of Prizren are presented in the following table. From the sample were done three analysis and the average is calculated. The final results are given in the following tables, where are shown physical and chemical characteristics.

Table 1. The final results of the experimental analysis (September-October 2016) ${ }^{[5]}$

\begin{tabular}{|c|c|c|c|c|c|c|}
\hline Parameters & $\begin{array}{l}\text { Symbol } \\
\text { S }\end{array}$ & Units & $\mathrm{AB} 1$ & $\mathrm{AB} 2$ & $\mathrm{AB} 3$ & $\mathrm{AB} 4$ \\
\hline \multicolumn{7}{|l|}{ Physical Parameters } \\
\hline Time & 00:00 & $\mathrm{h}$ & $12: 20$ & $12: 30$ & $14: 05$ & $14: 35$ \\
\hline Weather & Weth. & $\begin{array}{l}\text { Obser } \\
\text { ve }\end{array}$ & Sun & Sun & Sun & Sun \\
\hline Weather & Weth. & $\begin{array}{l}\text { Obser } \\
\text { ve }\end{array}$ & Sun & Sun & Sun & Sun \\
\hline Water Temperature & $\mathrm{T}_{\mathrm{w}}$ & ${ }^{0} \mathrm{C}$ & 18.6 & 20.7 & 19.5 & 17.0 \\
\hline \multicolumn{7}{|l|}{ Chemical Parameters } \\
\hline $\begin{array}{ll}\begin{array}{l}\text { Hydrogen } \\
\text { concentration }\end{array} & \text { ion } \\
\end{array}$ & $\mathrm{pH}$ & $0-14$ & 7.48 & 7.22 & 6.87 & 7.19 \\
\hline Ion phosphate & $\mathrm{PO}_{4}^{3-}$ & $\mathrm{mg} / \mathrm{L}$ & 0.0038 & 2.372 & 2.288 & 1.203 \\
\hline Total phos. & Ptot & $\mathrm{mg} / \mathrm{L}$ & 0.021 & 1.127 & 0.329 & 0.982 \\
\hline Phosphorus & $\mathrm{P}_{2} \mathrm{O}_{5}$ & $\mathrm{mg} / \mathrm{L}$ & 0.00 & 1.403 & 1.22 & 1.534 \\
\hline Sodium Tripolyphos. & $\mathrm{Na}_{3} \mathrm{PO}_{4}$ & $\mathrm{mg} / \mathrm{L}$ & 0.0 & 2.42 & 2.11 & 2.65 \\
\hline
\end{tabular}


Book of Proceedings

International Conference on Mechatronics, Sciences in Energy Efficiency Engineering,

System Engineering and Robotics

Table 2 Allowed limit values of parameters in effluent that can be discharged into water body or public sewage system and maximum allowed values by the Kosovo Administrative Instruction for drinking water, MAV (maximum allowable value) and categories of pollution are marked with K. --ADMINISTRATIVE INSTRUCTION No. 2008 on limit values of effluents discharged into water

\begin{tabular}{|c|c|c|c|c|c|c|c|}
\hline & $\mathbf{N j}$. & $\begin{array}{l}\text { K. } \\
\text { II }\end{array}$ & $\begin{array}{l}\text { K. } \\
\text { III }\end{array}$ & $\begin{array}{l}\text { K. } \\
\text { IV }\end{array}$ & $\begin{array}{l}\mathbf{K} . \\
\mathbf{V}\end{array}$ & $\begin{array}{l}\text { K. } \\
\text { VI }\end{array}$ & $\begin{array}{l}\text { Virg. } \\
\text { Wat.MAV }\end{array}$ \\
\hline $\begin{array}{l}\text { Ion phosphate } \\
\mathrm{PO}_{4}^{-3}\end{array}$ & $\mathrm{mg} / \mathrm{l}$ & 1,0 & 2,0 & 3,0 & 4,0 & - & 4.5 \\
\hline $\begin{array}{l}\text { Phosphorus } \\
\text { Pentoxide }\end{array}$ & $\mathrm{mg} / \mathrm{l}$ & 2.3 & 4.6 & 6.9 & 9.2 & 45 & 10.3 \\
\hline Tripoly- phos Na & $\mathrm{mg} / \mathrm{l}$ & 3.9 & 7.9 & 11.9 & 15.9 & 77.8 & 17.8 \\
\hline Total phosph. & $\mathrm{mg} / \mathrm{l}$ & 1,0 & $\mathbf{1 , 0}$ & 1,5 & 2,0 & 10,0 & 1.5 \\
\hline
\end{tabular}

Explanation: In this table on the KII-KV pillars are given the values of the parameters by categories for the wastewater discharge and on the last pillar KVI are given maximum values allowed in the public sewage network for drinking water.

\subsection{Ion of phosphorus concentrations and tripolyphosphate polluting detergents ingredient at the site-sampling "AB"}

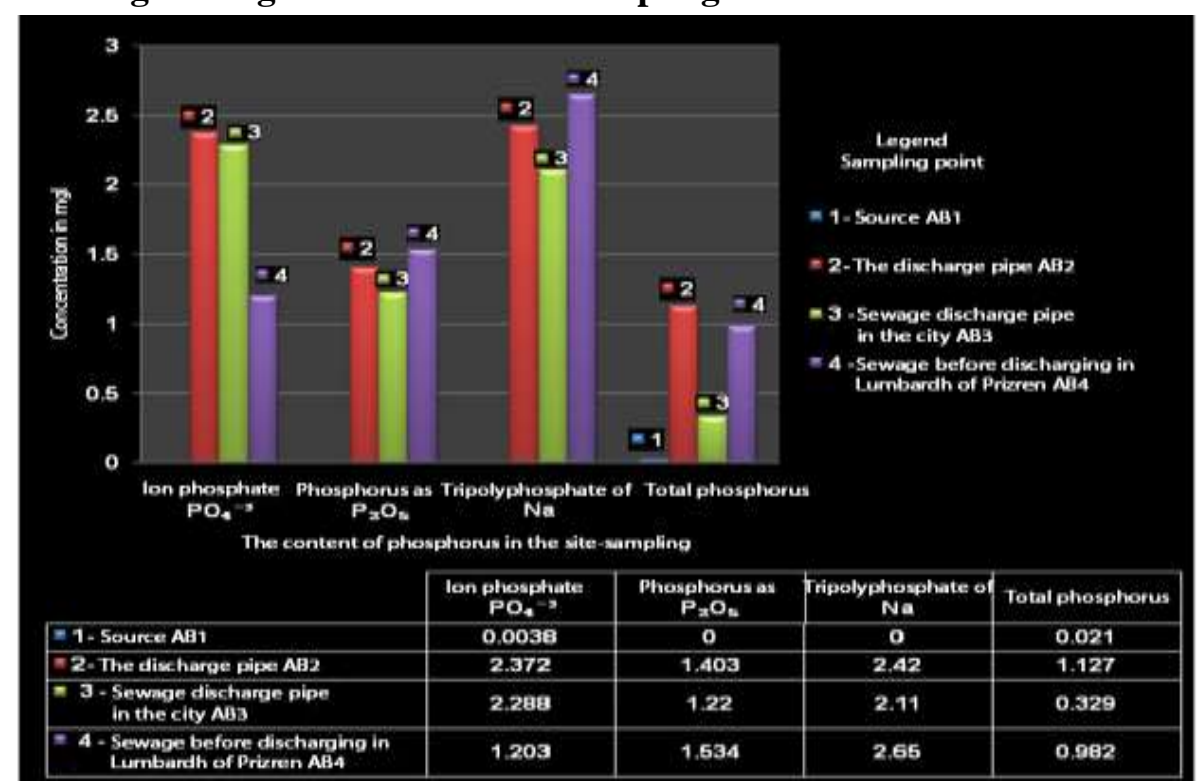

Fig.2. Graphic presentation of phosphorus concentration (September - October 2016) 
Physical-Chemical characteristics of the Substances Before and After the discharge of factories of the detergents that can cause increase of the degree of the eutrophication of surface waters in the city of Prizren

Table 3. Comparison of the values obtained at the sampling points with MAV - WHO (SeptemberOctober 2016)

\begin{tabular}{|c|c|c|}
\hline \multicolumn{3}{|c|}{ First sampling point } \\
\hline Chemical Parameters & $\begin{array}{l}\text { Source } A B_{1}- \\
\text { Obtained values }\end{array}$ & $\begin{array}{l}\text { Categary II } \\
\text { MAV }\end{array}$ \\
\hline Ion phosphate $\mathrm{PO}_{4}^{-3}$ & 0.0038 & 1.0 \\
\hline PhosphorusPentaoxide & 0.0 & 2.3 \\
\hline Sod.Tripolyphosphate & $\mathbf{0 . 0}$ & 3.9 \\
\hline Total phosphorus & 0.021 & 1.0 \\
\hline \multicolumn{3}{|c|}{$\begin{array}{l}\text { According to MAV the sampling point belongs to the second category, low } \\
\text { values of joint phosphate and total phosphorus at the virgin sampling point } \\
\text { comes due to the consist of apatit mineral in the water source. }\end{array}$} \\
\hline \multicolumn{3}{|c|}{ Second sampling point } \\
\hline Chemical Parameters & $\begin{array}{l}\text { Exhaust pipe } \\
\mathrm{AB}_{2}-\text { Obtained } \\
\text { values }\end{array}$ & Cat. Accord. to MAV \\
\hline Ion phos. $\mathrm{PO}_{4}^{-3}$ & 2.372 & 3.0 (Cat.IV) \\
\hline $\begin{array}{l}\text { Phosphorus } \\
\text { Pentaoxide }\end{array}$ & 1.403 & 2.3 (Cat.II) \\
\hline SodiumTripolyphos & 2.427 & 3.9 (Cat.II) \\
\hline Total phosphorus & 1.127 & 1.5 (Cat.IV) \\
\hline \multicolumn{3}{|c|}{$\begin{array}{l}\text { According to the MAV - WHO, parameters ion phosphate and total } \\
\text { phosphorus belong to the fourth categ. And phosphorus pentoxide and sodium } \\
\text { tripoly phosphate belong to the second category, there is a serious pollution } \\
\text { because manufacturing washing waters contain high concentration of } \\
\text { detergents. }\end{array}$} \\
\hline
\end{tabular}

\begin{tabular}{|l|l|l|}
\hline \multicolumn{2}{|c|}{ Third Sampling point } \\
\hline $\begin{array}{l}\text { Chemical } \\
\text { Parameters }\end{array}$ & $\begin{array}{l}\text { Exhaust pipe into the city sewage } \\
\mathrm{AB}_{3}-\text { Obtained values }\end{array}$ & $\begin{array}{l}\text { Cat. according to } \\
\text { MAV }\end{array}$ \\
\hline Ion phos. PO4 & -3 \\
2.288 & 3.0 (Kat.IV) \\
\hline $\begin{array}{l}\text { Phosph. } \\
\text { Pentoxide }\end{array}$ & 1.22 & 2.3 (Kat.II) \\
\hline Sod.Tripoly phos & 2.11 & 3.9 (Kat.II) \\
\hline Total phosphorus & 0.329 & 1.0 (Kat.II) \\
\hline
\end{tabular}


Book of Proceedings

International Conference on Mechatronics, Sciences in Energy Efficiency Engineering, System Engineering and Robotics

\begin{abstract}
According to allowed values from MAV, Ion phosphate parameters that belong to the fourth cat. and phosphorus pentoxide and sodium tripoly phosphate that belong to the second cat. there is a serious pollution due to manufacturing washing waters contain high concentration of detergents.
\end{abstract}

\begin{tabular}{|l|l|l|}
\hline \multicolumn{3}{|c|}{ Fourth sampling point } \\
\hline $\begin{array}{l}\text { Chemical } \\
\text { parameters }\end{array}$ & $\begin{array}{l}\text { Swage before discharge into } \\
\text { Lumbardhi of Prizren } \mathrm{AB}_{4}- \\
\text { Obtained values }\end{array}$ & $\begin{array}{l}\text { Cat. according to } \\
\text { MAV }\end{array}$ \\
\hline $\begin{array}{l}\text { Joni fosfat } \mathrm{PO}_{4}^{-} \\
\mathbf{3}\end{array}$ & $\mathbf{1 . 2 0 3}$ & $\mathbf{2 . 0}$ (kat. III) \\
\hline $\begin{array}{l}\text { Pentaoksidi i } \\
\text { fosforit }\end{array}$ & 1.534 & 2.3 (Kat.II) \\
\hline $\begin{array}{l}\text { Tripolifosfati i } \\
\text { Na }\end{array}$ & $\mathbf{2 . 6 5}$ & 3.9 (Kat.II) \\
\hline Fosfori total & $\mathbf{0 . 9 8 2}$ & 1.0 (Kat. II) \\
\hline $\begin{array}{l}\text { According to the allowed values from MAV sampling point shows } \\
\text { pollution. }\end{array}$ \\
\hline
\end{tabular}

Referring to the data in Figure1 and indicators in Table 3:

$\downarrow$ It is concluded that the concentration of phosphorus is too high into the drain of manufacturer of liquid detergent "AB" (AB2) and the discharge pipe into the city network sewage (AB3), due to the discharge of water after the production process. The main contributor to pollution of the waters is the detergent, in which sodium tripolyphosphate is used, which hydrolyzes slowly into water to form orthophosphate.

$\uparrow$ It is concluded that into the sewage before discharge into Lumbardhi (AB4) there are decreased values of these parameters, which represents pollution.

\title{
Conclusions
}

Based on the methodology in the study, we think that we have achieved in to determine the qualitative and quantitative water pollutants of discharged waters of detergents manufacturing factory AB into Lumbardhi. From the observation of our results as well as further monitoring shows that these discharging waters are not preliminary treated before discharge into Lumbardhi of Prizren.

$\downarrow$ Referring to the rates of the maximum values allowed by the of the EU directives and comparing them with our data, we can make the classification of the quality of discharging waters in our country. During physical chemical analyzes of the quality of the samples taken in the joint sampling sites, there are variations of joint phosphate, pentoxide phosphorus, sodium tripolyphosphate and total phosphorus. $\downarrow$ During our study we managed to make a comparison of our results obtained from physical- chemical analysis of water quality in sampling points which shows that the values of chemical parameters are larger at discharges from urban sewage network where it has its portion the detergents production factory AB into Lumbardhi River of Prizren. 
Physical-Chemical characteristics of the Substances Before and After the discharge of factories of the detergents that can cause increase of the degree of the eutrophication of surface waters in the city of Prizren

$\downarrow$ According to the obtained results, the chemical parameters of joint phosphate, pentoxide phosphorus, sodium tripolyphosphate and total phosphorus and through the

discussion of these results, resulted that these values are greater in Lumbardhi Prizren River. Just as we showed above, this comes from multiple sources of wastewater discharged into Lumbardhi and lack of pre-treatment plants before they are discharged into it.

\section{References}

1. Stanely E. Manahan: Environmental Chemistry, Fourth Edition, Williard Grant Press, Boston (1984).

2. Shakya, Suman K.: "Alarming Trends of River Pollution in Kathmandu, Nepal”, A Journal of the Environment, Volume 6, Number 7 . (2001).

3. Abdullah S,: Conditioning ecological and zonal distribution of the Bistrica River makrozoobentosit in Prizren, page 2 - 5. Prizren (1979)

4. Alqi C,: Environmental Chemistry,page 127, 157- 158, 194 - 195. Tirana (2010)..

5. Anonym, Methods Standard ISO 9001: Hydrometeorology, Institute of Kosovo, page 3 - 7, Pristina (2011)

6. Elmaz SH,: Chemical Technology and Environment, page 116, 334 - 335.Tirana , (2009)

7. Nexhat D, : Environmental Chemistry, page 11 - 16 . Prishtinë (1998)

8. Sabahidin V,: Sanitary protection Lumbardhi bedding from sewage pollution. Project of the municipalityof Prizren, page 2- 4. Pristina (2011) 